\title{
A Case of Traumatic Myiasis in a Domestic Rabbit (Oryctolagus cuniculus) Caused By Lucilia sericata
}

Evcil Bir Tavşanda (Oryctolagus cuniculus) Lucilia sericata’nın Neden Olduğu Travmatik Myiasis Olgusu

\section{Duygu Neval Sayın İpek', Polat Ipek²}

'Department of Parasitology, Faculty of Veterinary Medicine, Dicle University, Diyarbakır, Turkey 'Livestock Unit, GAP International Agricultural Research and Training Centre, Diyarbakır, Turkey

\begin{abstract}
Lucilia sericata is one of the factors resulting in facultative traumatic myiasis in animals and humans. L. sericata threatens human health and leads to significant economic losses in animal industry by leading to serious parasitic infestations. A three month old female rabbit was presented to the clinics of the Veterinary Faculty of Dicle University for the treatment of the wound located on the left carpal joint. The examination revealed that the wound was infested with larvae. The microscopic inspection of the larvae collected from the rabbit showed that they were the third instar larvae of L. sericata. (Turkiye Parazitol Derg 2012; 36: 54-6)
\end{abstract}

Key Words: Lucilia sericata, myiasis, rabbit

Received: 18.08.2011

Accepted: 16.12 .2011

\section{ÖZET}

Lucilia sericata fakültatif travmatik myiasis etkenlerinden biri olup, önemli paraziter enfestasyonlara yol açarak hem insan sağlığı hem de hayvancılık ekonomisine büyük zararlar vermektedir. Dicle Üniversitesi Veteriner Fakültesi kliniklerine sol karpal ekleminde yara şikayeti ile 3 aylık dişi bir tavşan getirilmiştir. Yara muayenesinde yaranın larvalarla enfeste olduğu belirlenmiştir. Yaradan toplanan larvaların mikroskobik incelemesi sonucunda bu larvaların 3. dönem L. sericata larvaları olduğu saplanmıştır.

(Turkiye Parazitol Derg 2012; 36: 54-6)

Anahtar Sözcükler: Lucilia sericata, myiasis, tavşan

Geliş Tarihi: 18.08.2011

Kabul Tarihi: 16.12 .2011

\section{INTRODUCTION}

Traumatic or wound myiasis is a parasitic infestation caused by the feeding of fly larvae on the cutaneous tissues in traumatic lesions of their vertebrate hosts $(1,2)$. Several species of myiasis-causing flies were reported to parasitize the domestic rabbit such as the cuterebrids: Cuterebra buccata, C. cuniculi, C. horripi lum, C. lepivora, as well as the calliphorids: Lucilia sericata, L. eximia, Cochliomyia hominivorax and humanbotfly: Dermatobia hominis (3-8).
The 'greenbottle' blowfly, Lucilia sericata (Meigen) larvae is an facultative parasite of mammals which is an important pest of the livestock industries in temperate countries (9). The cause of involvement in rabbits is almost always the blowfly $L$. sericata, the same species that infests sheep in northern Europe $(9,10)$. The feeding activity larvae may cause severe tissue damage resulting in loss of production, septicemia and shock, which lead to rapid death of the rabbit (11).

There are reports in the literature of several domestic animals infested by L. sericata, such as bovines, caprines, dogs,

Address for Correspondence / Yazışma Adresi: Dr. Duygu Neval Sayın İpek, Dicle Üniversitesi Veteriner Fakültesi, Parazitoloji Anabilim Dalı, Diyarbakır, Turkey Phone: +90 4122488020 E-mail: dnsayin@hotmail.com doi:10.5152/tpd.2012.14 
cats, sheep, gazelles in Turkey (12-15). However, reports of the occurrence of traumatic myiasis by $L$. sericata in this host have not been described previously. The present study is the first to report a case of infestation by $L$. sericata in the domestic rabbit (Oryctolagus cuniculus) in Turkey.

\section{CASE PRESENTATION}

A three month old female rabbit was brought to the clinics of the Veterinary Faculty of Dicle University in May 2011 for treatment of the wound located on her left carpal joint (Figure 1). The examination revealed that the wound was infested with larvae, which were collected using fine tweezers. A sterile salty solution was used to clean the wound and a thin layer of creoline was applied to the wound to remove the larvae that were invisible to the naked eye and were deeply imbedded. The rabbit was put on a non-steroidal pain reliever $(0.2 \mathrm{mg} / \mathrm{kg}, \mathrm{IM}$, meloxicam, Maxicam, Sanovel, İstanbul) and antibiotic (100 mg, IM, sefazolin sodium, Cefamezin 1gr flakon, Eczacıbaşı, İstanbul-Türkiye), and monitored in the clinic.

We collected 86 viable larvae, which were washed and then placed in a petri dish and fixed with $70 \%$ hot alcohol. After completely cooling them, the larvae were placed in fresh alcohol. After disrupting them at a couple of different sites of the body using lancets, the larvae were kept in bottles containing 30\% potassium hydroxide $(\mathrm{KOH})$ until they became transparent. Later, the sections that enabled determination of the species and specific stage of the life cycle of the larvae were dissected from the transparent larvae under stereo microscope and were mounted on slides using mounting $\mathrm{CM}$ medium and species identification was performed in compliance with relevant literature reports $(16,17)$.

The microscopic inspection of the larvae collected from the rabbit showed that they were the third instar larvae of $L$. sericata. The third instar larvae were 9-12 mm in length (Figure 2a) and they had the pharyngeal skeleton anterior spiracles and posterior spiracles. Anterior spiracles each had 8-9 branches. Posterior spiracles had buttons with three grooves. Relevant parts of the larvae were pictured and illustrated in Figure 2b, c.

\section{DISCUSSION}

The species belonging the Calliphoridae and Sarcophagidae families of Diptera order cause various forms of myiasis in ani- mals and humans. While obligatory parasites belonging to these families and causing myiasis can live on the surface of or inside the host, facultative parasites resulting in myiasis can also live on a decomposed host. Myiasis creates serious health problems in domestic animals and causes significant economic losses $(18,19)$. While myiasis mostly affects sheep, it is also encountered in various domestic and wild animals. W. magnifica and L. sericata are shown to be the primary species causing traumatic myiasis in Turkey $(12,13,20)$.

The presence of myiasis in domestic rabbits in the United Kingdom are reported to be a common problem and are frequently encountered in veterinary surgery. While myiasis cases caused by Cuterebra sp in rabbits are shown to be encountered in the United States only, L. sericata is reported to be responsible for the majority of myiasis cases in northern Europe $(9,10$, 21-23). Moreover, L. eximina has been shown to cause traumatic myiasis in a pet rabbit for the first time and D. hominis is demonstrated to result in furuncular myiasis a New Zealand rabbit in Brazil $(6,8)$. While L. sericata is reported to cause traumatic myiasis in animals and humans, its involvement in the myiasis of domestic rabbit has not been reported in Turkey, so the present case is the first report. All the larvae collected from the rabbit in this study belonged to $L$. sericata, a finding consistent with previ-

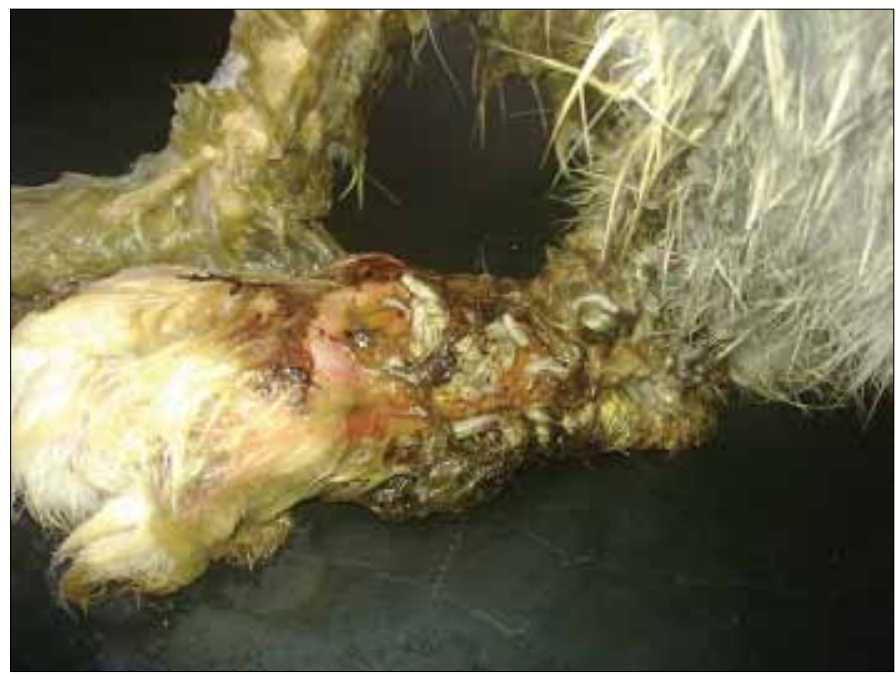

Figure 1. Traumatic myiasis of domestic rabbit and larvae of L. sericata

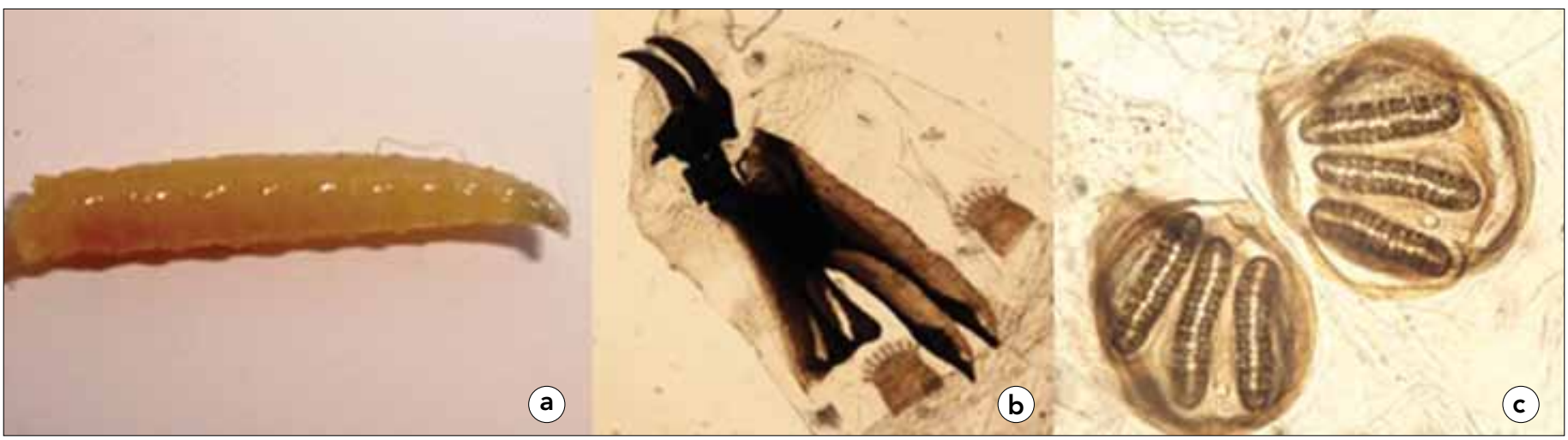

Figure 2. a) Third-stage larvae of L. sericata; b) Pharyngeal Scleton c) Posterior Spiracle 
ous studies and further verifying the statement that the primary factor for myiasis cases in Turkey is L. sericata. Moreover, this case indicates that an increased insect population during the spring and summer months increases the risk of myiasis cases in rabbits as in other domestic animals $(14,15,20,24)$.

In conclusion, the presence of traumatic myiasis cases in rabbits, kept as pets or bred for their meat and fur, should be watched carefully to maintain their health. Determining insect fauna in various regions of Turkey is critical in order to minimize the development of serious diseases owing to myiasis in animals and avoid economic losses. In addition, animal rbreeders should be trained concerning the fight against flies causing myiasis; open wounds in animals should be treated promptly. Wastes, corpses, and other organic materials that facilitate growth of insects should be removed from the environment and the care and feeding conditions of animals should be improved.

\section{Conflict of Interest}

No conflict of interest was declared by the authors.

\section{REFERENCES}

1. Hall MJ. Traumatic myiasis of sheep in Europe: a review. Parassitologia 1997; 39: 409-13.

2. Hall MJ, Farkas R. Traumatic myiasis of humans and animals. Papp L, Darvas B, editors. Contributions to a Manual of Palaearctic Diptera. Science Herald, Budapest; 2000. p. 751-68.

3. Jacobson HA, McGinnes BS, Catts EP. Bot fly myiasis of the cottontail rabbit, Sylvilagus floridanus mallurus, in Virginia with some biology of the parasite, Cuterebra buccata. J Wildl Dis 1978; 14: 56-66.

4. Meredith A. Skin diseases of rabbits. Ir Vet J 2003; 56: 52-6.

5. Bisdorff B, Wall R. Blowfly strike prevalence in domestic rabbits in southwest England and Wales. Vet Parasitol 2006; 141: 150-5. [CrossRef]

6. Moretti TC, Thyssen PJ. Miíase primária em Coelho doméstico causada por Lucilia eximia (Diptera: Calliphoridae) no Brasil: relato de caso. Arq Bras Med Vet Zootec 2006; 58: 28-30. [CrossRef]

7. Scott DW, Miller WH, Griffin CE. Dermatoses of Pet Rodents, Rabbits, and Ferrets. Scott DW, Miller WH, Griffin CE, editors. Muller \& Kirk's Small Animal Dermatology. Sixth Edition. Saunders Company, Philadelphia, PA; 2001. p. 1415-58.
8. Verocai GG, Fernandes JI, Ribeiro FA, Melo RMPS, Correia TR, Scott FB. Furuncular myiasis caused by the human botfly, Dermatobia hominis, in the domestic rabbit. J Exot Pet Med 2009; 18: 153-5. [CrossRef]

9. Hall MJR, Wall R. Myiasis of humans and domestic animals. Adv Parasitol 1995; 35: 257-334. [CrossRef]

10. French NP, Wall R, Morgan KL. The seasonal pattern of sheep blowfly strike in England and Wales. Med Vet Entomol 1995; 9: 1-8. [CrossRef]

11. Van Prag E: Myiasis (fly strike) in rabbits. MediRabbit 2003. Available from: URL. http://www.medirabbit.com/EN/Skin_diseases/Parasitic/ Myiasis/Miyasis_fly.htm Erişim Tarihi: 15/07/2011

12. Şaki CE, Özer E. Elazığ ve çevresinde sığır, koyun ve keçilerde myiasisler ve bunlarnn tedavileri. Turk J Vet Anim Sci 1999; 23: 261-8.

13. Sayın İpek DN, Şaki CE. Diyarbakır ve Yöresinde Sığır, Koyun ve Keçilerde Eksternal Myiasisler. Dicle Üniv Vet Fak Derg 2010; 1: 1- 7.

14. Eren H, Aypak S, Ural K, Seven F. Lucilia sericata (Diptera: Calliphoridae) larvalarına bağı kedide ocular ve köpekte travmatik myiasis olguları. Kafkas Univ Vet Fak Derg 2010; 16: 883-6.

15. Sevgili M, Şaki CE, Gökçen A. Bir ceylanda genital myiasis olgusu. T Parazitol Derg 2004; 28: 202-4.

16. Clark EW, Morishita F. C-M medium: A mounting medium for small insects, mites and other whole mount. Science 1950; 112: 789-90. [CrossRef]

17. Zumpt F. Myiasis in man and animals in the old world. Butterwoths and Co. Itd. London; 1965.

18. Kettle DS. Medical and Veterinary Entomology. CAB International, Wallingford; 1990. p. 241-61.

19. Wall R, Shearer D. Veterinary Entomology. Chapman\&Hall, London; 1997. p. 197-250. [CrossRef]

20. Dik B, Uslu U, Işık N. Myiasis in Animals and Humanbeings in Turkey. Kafkas Univ Vet Fak Derg (Article in Press).

21. Beynon PH, Cooper JE. Rabbits. In: Manual of Exotic Pets. Second Edition. BSAVA; 1991. p. 69-81.

22. Cousquer, GO. Veterinary care of a giant lop rabbit withsevere fly strike. WorldWide Wounds 2006. Available from:URL: http://www. worldwidewounds.om/2006/february/Cousquer/Veterinary-LopRabbit-Fly-Strike.html Erişim Tarihi: 12/06/2011.

23. Cousquer, GO. Veterinary care of rabbits with fly strike. In Practice 2006; 28: 342-9. [CrossRef]

24. Sayın İpek DN, Şaki CE, Özer E. Diyarbakır ve Çevresinde Eksternal Myiasis Etkenleri ve Mevsimsel Dağılımları. Kafkas Univ Vet Fak Derg 2011; 17: 469-75. 